\title{
Estimating Atherosclerosis Cardiovascular Disease Risk of 10-year with the Systemic Coronary Risk Estimation Method and Statin Use Recommendation
}

\author{
Nurmainah ${ }^{1}$, Syarifah N.Y.R.S Asseggaf ${ }^{2}$ \\ ${ }^{1}$ Department of Pharmacology and Clinical Pharmacy, Faculty of Medicine, Tanjungpura University, \\ Pontianak, West Kalimantan, Indonesia \\ ${ }^{2}$ Department of Pharmacology, Faculty of Medicine, Tanjungpura University \\ Pontianak, West Kalimantan, Indonesia
}

\begin{abstract}
Stroke and heart disease belong to atherosclerotic cardiovascular diseases (ASCVD), which is one of the death causes in Indonesia. This study aimed to estimate the risk of atherosclerosis cardiovascular disease in the next 10 years using the Systemic Coronary Risk Estimation (SCORE) method. This research was an observational study with descriptive cross-sectional study design. Respondent data collection was taken prospectively which means directs data was collected through interviews, blood pressure measurement, and peripheral blood sampling. The results showed that respondents who were involved in this study were those with an average age of $49.70 \pm 7.1$ years. Respondents were more dominated by women $(76.1 \%)$; BMI of respondents showed in the non-obese group $27.14 \pm 4.6 \mathrm{~kg} / \mathrm{m}^{2}$; total cholesterol, LDL, TG, and HDL levels respectively had an average of $152.17 \pm 39.5 \mathrm{mg} / \mathrm{dL} ; 91.28 \pm 40.9$ $\mathrm{mg} / \mathrm{dL} ; 117.24 \pm 96.9 \mathrm{mg} / \mathrm{dL}$; and $30.87 \pm 8.8$. The number of respondents who smoke was $17.39 \%$ and that of those who have undergone physical activity in the form of sports was $60.87 \%$. Based on the results of risk estimation using the SCORE method, it was found that the number of people who were in the low-risk category was $54.35 \%$ and the moderate risk category was $45.65 \%$. This study concludes that the risk of ASCVD for the next 10 years in the community is at low and moderate levels. Non-pharmacological treatment is more recommended at this level and statins can be given to individuals if there is no improvement in cholesterol levels.
\end{abstract}

Keywords: Atherosclerosis Cardiovascular Siseases (ASCVD), SCORE, Statins

\section{Introduction}

Non-communicable disease (NCD) is one of the factors causing death in Indonesia. Based on statistical data from the World Health Organization (WHO), the percentage of deaths caused by NCD in Indonesia is $73 \%$ of the total population (258 million people).
One of the NCDs which can cause death is cardiovascular disease, with as many as 17.7 million people affected. ${ }^{1}$ In Indonesia, the prevalence of death caused by cardiovascular is $17.3 \% .^{2}$ On the other hand, the burden of costs that must be incurred by the Indonesian government to overcome the cardiovascular

Corresponding author: Nurmainah. Pharmacology and Pharmacy Clinic Departement, Faculty of Medicine, Tanjungpura

University, Pontianak, West Kalimantan, Indonesia. Email: nurmainah@pharm.untan.ac.id

Received: 29 March 2020. Revised: 15 December 2020 . Published: 31 December 2020 
disease is very large. For example, the cost of treating heart disease during 2014-2016 covered by Indonesian government health insurance is Rp. 7.9 trillion. $^{3}$

West Kalimantan is one the provinces in Indonesia with high cases of cardiovascular disease. The prevalence of cardiovascular diseases is relatively high. For instance, heart disease $(0.3 \%)$, stroke $(0.08 \%)$, heart failure $(5.8 \%)$, and hypertension (28.3\%). Among many cases around the cities in Indonesia with four types of cardiovascular diseases, the number of cases for heart disease in West Kalimantan is the third highest figure. ${ }^{4}$ One of many causes of cardiovascular diseases is dyslipidemia. In addition, cholesterol levels in the population with $\geq 15$ years of age in Indonesian vary. The proportion of very high low density lipoprotein (LDL) level $(\geq 190$ $\mathrm{mg} / \mathrm{dl})$ is $15.9 \%$; high density lipoprotein (HDL level ( $<40 \mathrm{mg} / \mathrm{dl})$ is $22.9 \%$; and very high triglycerides level $(\geq 500 \mathrm{mg} / \mathrm{dl})$ is $11,9 \% .{ }^{4}$ People with high cholesterol level are at risk of atherosclerosis cardiovascular disease (ASCVD). Therefore, it is necessary to predict the risk of ASCVD.

We aimed to estimate the risk of ASCVD early so that an appropriate prevention and management program for ASCVD can be taken. Several methods can be used to predict the risk of cardiovascular diseases such as Framingham, Systemic Coronary Risk Estimation (SCORE), ASSIGN, Q-Risk, Prospective Cardiovascular Munsters Study (PROCAM), WHO/ISH, and the Pooled Cohort Equations.

All methods which assess cardiovascular disease risk have the same ability in predicting ASCVD. However, each clinical management guideline uses a system of cardiovascular risk estimation. ${ }^{5,6}$ In Indonesia, the risk prediction method for ASCVD used in clinical practice is the SCORE method. ${ }^{7}$

The SCORE method is used to predictASCVD for patients aged $\geq 40$ years. The patients were known to have no evidence of suffering from coronary heart disease (CHD), diabetes mellitus (DM), chronic kidney disease (CKD), and familial hypercholesterolemia. ASCVD risk levels are grouped into four levels namely very high risk (10-years risk score $\geq 10 \%$ ), high risk ( 10 -years risk score $\geq 5 \%$ and $<10 \%$ ), moderate risk ( 10 -years risk score $\geq 1 \%$ and $<5 \%$, and low risk ( 10 -years score $<1 \%$ ). The results of the risk grouping will be adjusted to the recommendation of using statins based on dyslipidemia guidelines published by The Indonesian Cardiovascular Specialist Association (PERKI) 2017. ${ }^{7}$ So far, there have been some cases where statin is prescribed inappropriately in Asia, not to mention in Indonesia. ${ }^{8,9}$ This is due to the selection of statin has not yet consider the risk of ASCVD as stated in the guidelines of PERKI 2017. The proper prescription of statin could prevent the risk of ASCVD and it has a positive impact on the health care. ${ }^{10}$

\section{Methods}

\section{Research Ethics}

The study was conducted in Baru Village which is one of the working areas of the Sungai Raya Dalam Community Health Center, Kubu Raya Regency, West Kalimantan, Indonesia. This study has passed the ethical-clearance study from the Ethics Review Division of the Faculty of Medicine at Universitas Tanjungpura (No.3963/UN22.9/DL/2019).

\section{Research Design}

The research method used in this study was an observational method with descriptive cross-sectional study design. The respondents were community in Baru Village, Kubu Raya Regency, West Kalimantan, Indonesia. 


\section{Respondent Criteria}

The inclusion criteria of respondents:

1. Aged 40-65 years,

2. Had been fasting for 8 hours before blood samples were taken,

3. Were ready to sign informed consent.

Exclusion criteria of respondents:

1. Had a history of previous cardiovascular disease, blood pressure measurement was not possible,

2. Were pregnant or unable to communicate verbally,

3. $\mathrm{SBP}>220 \mathrm{mmHg}$,

4. A total cholesterol level $>310 \mathrm{mg} / \mathrm{dl}$ or $<130 \mathrm{mg} / \mathrm{dl}$, and

5. Incomplete data.

\section{Data Collection ${ }^{11}$}

Data collection was carried out by interviews with respondents using a case report form (CRF) sheet to obtain information about gender, age, hypertension drug use, and smoking status of the respondents, as well as to ensure that respondents who came were those who had truly fulfilled all inclusion and exclusion criteria from the study.

Furthermore, the respondents are measured for blood pressure by positioning them to sit upright in a chair and rest for about 5 minutes first. Blood pressure measurements were carried out on the respondent's left hand, first ascertained on the respondent's left arm. No objects or jewelry could affect the measurement results and made it difficult for researchers to take measurements. Then the left arm was positioned on a par with the heart and a digital sphygmomanometer was mounted on the respondent's arm then measurements of systolic blood pressure (SBP) and diastatic blood pressure (DBP) were performed. Measurement of blood pressure was done 2 times with an interval of 2 minutes. If the results of the second measurement differed by $\geq 10 \mathrm{mmHg}$, a third measurement and two results close to the average will be measured.

In the next stage, the respondents had to undertaken peripheral blood samples by the clinician. The amount of blood sample needed was as much as $5 \mathrm{cc}$ to measure cholesterol levels. The blood sample used to measure the level of total cholesterol, low density lipoprotein (LDL), high density lipoprotein (HDL), and triglyceride was taken by a device from LipidPro ${ }^{\circledR}$. After that, the result is analyzed by using The SCORE method in order to find the risk of ASCVD from each respondent. This method was carried out using the Heart SCORE High Risk at http:// www.heartscore.org/en_GB.

\section{Cardiovascular Risk Stratification}

The atherosclerotic cardiovascular disease (ASCVD) risk score into four catagories: very high risk (10-years risk score $\geq 10 \%$ ), high risk ( 10 -years risk score $\geq 5 \%$ and $<10 \%$ ), moderate risk ( 10 -years risk score $\geq 1 \%$ and $<5 \%$, and low risk ( 10 -years score $<1 \%$ ).

\section{Results and Discussion}

The number of respondents involved in this study was 46 respondents, with the characteristics of respondents that can be seen in Table 1.

Some factors which affect the risk of ASCVD can be seen from the lab data such as the total of cholesterol level, TG, HDL, LDL, and SBP. The data above shows the risk level of having ASCVD from each individual. ${ }^{12}$ Data on total cholesterol levels indicate that respondents have total cholesterol levels below $200 \mathrm{mg} /$ dL. Some studies explains that an increase in total cholesterol levels is associated with dyslipidemia. $^{9,13}$ This is because with an increase in total cholesterol levels, there will be an increase in the number of monocytes in the blood. Monocytes are found in the walls 
Table 1. Characteristics of Respondents $(\mathrm{N}=46)$

\begin{tabular}{lc}
\hline Parameter & Value (\%) \\
\hline Age (Years) & $49.70 \pm 7.1$ \\
Gender & \\
Male & $11(23.9)$ \\
Female & $35(76.1)$ \\
BMI $\left(\mathrm{kg} / \mathrm{m}^{2}\right)$ & $27.14 \pm 4.6$ \\
Total cholesterol (mg/dL) & $152.17 \pm 39.5$ \\
LDL (mg/dL) & $91.28 \pm 40.9$ \\
TG (mg/dL) & $117.24 \pm 96.9$ \\
HDL (mg/dL) & $30.87 \pm 8.8$ \\
SBP (mmHg) & $142.13 \pm 23.2$ \\
DBP (mmHg) & $87.74 \pm 14.7$ \\
Antihypertensive Consumption & $9(19.56)$ \\
Aspirin Consumption & $1(2.17)$ \\
Statin Consumption & $4(8.69)$ \\
Physicial Activity & $28(60.87)$ \\
Smoked & $8(17.39)$ \\
\hline
\end{tabular}

Note:

$\mathbf{B M I}=$ Body Mass Index $\quad$ HDL $=$ High Density Lipoprotein

$\mathbf{L D L}=$ Low Density Lipoprotein $\mathbf{S B P}=$ Systolic Blood Pressure

$\mathbf{T G}=$ Triglyceride

DBP $=$ Diastolic Blood Pressure

of the inflamed arteries, which later turn into macrophages and phagocyte cholesterol. The process is the beginning of the formation of plaque in atherosclerosis which ultimately causes coronary heart disease. On the other hand, high total cholesterol levels affect free fatty acids that can cause free fatty acids to increase. The increase of fatty acids can trigger pancreatic beta-cell damage so that it can trigger the risk of diabetes mellitus. ${ }^{14}$

Overview of LDL Cholesterol Levels Based on ASCVD Risk Level

It can be seen in Table 2 that the people of Parit Baru Village, Kubu Raya Regency, after estimating the measurement of atherosclerosis cardiovascular risk for the next 10 years, were on mild risk of $56.52 \%$ and a moderate risk of $43.47 \%$. Based on the dyslipidemia guidelines issued by PERKI in 2017, it is stated that people with an estimated level of cardiovascular risk generally do not require lipid repair interventions. For those with low risk with LDL levels $<70 \mathrm{mg} / \mathrm{dL} ; 70-100 \mathrm{mg} /$ $\mathrm{dL}$; and $100-<155 \mathrm{mg} / \mathrm{dL} ; 155-<190 \mathrm{mg} / \mathrm{dL}$, lipid intervention is not necessary. However, it is different for those who have a low risk with LDL levels $\geq 190 \mathrm{mg} / \mathrm{dL}$, in the case that they require lifestyle intervention and if there is no change then the community should be given additional statin drugs with low intensity.

People at moderate risk with LDL levels $<70 \mathrm{mg} / \mathrm{dL}$ and $70-100 \mathrm{mg} / \mathrm{dL}$ do not need lipid repair interventions. However, people with moderate risk who have LDL levels of $100-<155 \mathrm{mg} / \mathrm{dL} ; 155-<190 \mathrm{mg} / \mathrm{dL}$; and $>$ 
Table 2. Overview of LDL Cholesterol Levels Based on ASCVD Risk Levels

\begin{tabular}{lccccccc}
\hline & \multicolumn{7}{c}{ Cholesterol Value (LDL) } \\
\cline { 2 - 8 } ASCVD risk level & $\begin{array}{c}<70 \\
(\mathrm{mg} / \mathrm{dL})\end{array}$ & $\begin{array}{c}70-100 \\
(\mathrm{mg} / \mathrm{dL})\end{array}$ & $\begin{array}{c}100-<155 \\
(\mathrm{mg} / \mathrm{dL})\end{array}$ & $\begin{array}{c}155- \\
<190 \\
(\mathrm{mg} / \mathrm{dL})\end{array}$ & $\begin{array}{c}>190 \\
(\mathrm{mg} / \mathrm{dL})\end{array}$ & $\begin{array}{c}\text { Total } \\
\mathrm{n}\end{array}$ & Percentage \\
\hline Low $(<1 \%)$ & $\mathrm{n}=10$ & $\mathrm{n}=8$ & $\mathrm{n}=6$ & $\mathrm{n}=1$ & $\mathrm{n}=1$ & 26 & $56.52 \%$ \\
& $21.74 \%$ & $17.39 \%$ & $13.04 \%$ & $2.17 \%$ & $2.17 \%$ & & \\
Moderate (1-5\%) & $\mathrm{n}=7$ & $\mathrm{n}=5$ & $\mathrm{n}=7$ & $\mathrm{n}=1$ & 0 & 20 & $43.47 \%$ \\
& $15.22 \%$ & $10.87 \%$ & $15.22 \%$ & $2.17 \%$ & & & \\
& & & & & & & \\
& & & & & & & \\
\end{tabular}

Table 3. High, Moderate, Low Intensity Statin Therapy ${ }^{7}$

\begin{tabular}{|c|c|c|c|}
\hline LDL-C lowering & High Intensity & Moderate Intensity & Low Intensity \\
\hline & $\geq 50 \%$ & $30-50 \%$ & $<30 \%$ \\
\hline Statin & $\begin{array}{l}\text { Atorvastatin } 40-80 \mathrm{mg} \\
\text { Rosuvastatin } 20-40 \mathrm{mg}\end{array}$ & $\begin{array}{c}\text { Atorvastatin } 10-20 \mathrm{mg} \\
\text { Rosuvastatin } 5-10 \mathrm{mg} \\
\text { Simvastatin } 20-40 \mathrm{mg} \\
\text { Pravastatin } 40-80 \mathrm{mg} \\
\text { Lovastatin } 40 \mathrm{mg} \\
\text { Fluvastatin XL } 80 \mathrm{mg} \\
\text { Fluvastatin } 40 \mathrm{mg} 2 \text { times/day } \\
\text { Pitavastatin 2-4 mg }\end{array}$ & $\begin{array}{l}\text { Simvastatin } 10 \mathrm{mg} \\
\text { Pravastatin } 10-20 \mathrm{mg} \\
\text { Lovastatin } 20 \mathrm{mg} \\
\text { Fluvastatin } 20-40 \mathrm{mg} \\
\text { Pitavastatin } 1 \mathrm{mg}\end{array}$ \\
\hline
\end{tabular}

$190 \mathrm{mg} / \mathrm{dL}$, non-pharmacological treatment needs lifestyle improvement and statin administration. The selection of statin drugs in people with moderate risk can be seen in Table 3 . The selection of statins in Table 3 must be attended to their availability in the National Formulary.

LDL cholesterol is the main factor of risk for having cardiovascular such as ASCVD. ${ }^{12}$ The increasing level of LDL cholesterol may result in the accumulation of cholesterol in the blood vessel which can trigger atherosclerosis. Statin can be prescribed to the patients with the level of LDL $\geq 190 \mathrm{mg} / \mathrm{dL} .^{7}$ Therefore, it is essential to use statin and to make it the main option in reducing the level of LDL so that it can be done optimally. Statin slows down the enzim HMG-CoA reductase. It also prevents the conversion of $\mathrm{HMG} \mathrm{CoA}$ reductase to mevalonate which cause the synthesis of LDL unable to be formed and catabolism of LDL will rise through LDL receptor. The prescription of statin can significantly avoid the risk of ASCVD and death due to cardiovascular disease. It also known that the use of statin is crucial for primer prevention of cardiovascular as much as 5\% and 30\% for secondary prevention. ${ }^{15,16}$

\section{Conclusion}

It can be concluded that the community of Parit Baru Village, Kubu Raya Regency has a risk of ASCVD in the next 10 years with low and moderate levels. Non-pharmacological treatment is more recommended at this level and statins can be given to individu if there is no improvement in cholesterol levels. 
Given these findings, further research should be carried out with large samples in different area of west Kalimantan, Indonesia. Thus, high risk or very high risk cardiovascular community and need intervention statin use to reduce morbidity and mortality.

\section{Acknowledgement}

The researchers would like to thank Universitas Tanjungpura for providing facilities and opportunities to develop this research to completion. Furthermore,we also thank the people of Parit Baru village, Kubu Raya Regency for their participation in this research.

\section{Funding}

This work was supported by the 2019 DIPA funding from Faculty of Medicine, Universitas Tanjungpura.

\section{Conflict of Interest}

None declared

\section{References}

1. World Health Organization. Noncommunicable Diseases (NCD) Country Profiles. 2018.

2. Kementerian Kesehatan Republik Indonesia. Situasi Kesehatan Jantung. Jakarta: Pusat Data dan Informasi Kementerian Kesehatan Republik Indonesia; 2014.

3. Kesehatan BPJS. Lindungi Diri sejak Dini dari Penyakit Jantung [Internet]. 2017 [cited 2019 Mar 6]. Available from: https://bpjs-kesehatan.go.id/bpjs/index. php/post/read/2017/551/Lindungi-DiriSejak-Dini-dari-Penyakit-Jantung.

4. Badan Penelitian dan Pengembangan Kementerian Kesehatan Republik Indonesia. Hasil Riset Kesehatan Dasar (RISKESDAS) 2013. Jakarta: Kementerian Kesehatan Republik Indonesia; 2014. 258-260 p.
5. Garg N, Muduli SK, Kapoor A, Tewari S, Kumar S, Khanna R, et al. Comparison of different cardiovascular risk score calculators for cardiovascular risk prediction and guideline recommended statin uses. Indian Heart Journal. 2017;69(4):458-63.

6. Selvarajah S, Kaur G, Haniff J, Cheong $\mathrm{KC}$, Hiong TG, Van Der Graaf Y, et al. Comparison of the Framingham Risk Score, SCORE and WHO/ISH cardiovascular risk prediction models in an Asian population. International Journal of Cardiology. 2014;176(1):2118.

7. Erwinanto, Santoso A, Putranto J, Tedjasukmana P, Sukmawan R, Suyawan R. Panduan Tata Laksana Dislipidemia 2017. Jakarta: Perhimpunan Dokter Spesialis Kardiovaskular Indonesia; 2017. 1-49 p.

8. Park JE, Chiang CE, Munawar M, Pham GK, Sukonthasarn A, Aquino $A R$, et al. Lipid-lowering treatment in hypercholesterolaemic patients: The CEPHEUS Pan-Asian survey. European Journal of Preventive Cardiology. 2012;19(4):781-94.

9. Iskandar MF, Nurmainah N, Susanti R. The Risk of Atherosclerotic Cardiovascular Disease among Hyperlipidaemia Patients and Appropriateness of Statin Therapy. Pharmacology and Clinical Pharmacy Research. 2018;3(1).

10. Stone NJ, Robinson JG, Lichtenstein AH, Bairey Merz CN, Blum CB, Eckel RH, et al. 2013 ACC/AHA guideline on the treatment of blood cholesterol to reduce atherosclerotic cardiovascular risk in adults: A report of the american college of cardiology/american heart association task force on practice guidelines. Circulation. 2014;129(25 SUPPL. 1):145.

11. Dwivani C, Harijadi K, Suhadi R. 
Perbandingan Lima Metode Estimasi Risiko 10 Tahun Penyakit Kardiovaskuler pada Masyarakat Kabupaten SlemanYogyakarta. Jurnal Manajemen dan Pelayanan Farmasi. 2018;8(2):59-69.

12. Mach F, Baigent C, Catapano AL, Koskinas KC, Casula M, Badimon L, et al. 2019 ESC/EAS Guidelines for the management of dyslipidaemias: Lipid modification to reduce cardiovascular risk. European Heart Journal. 2020;41(1):111-88.

13. Liu ML, Reilly MP, Casasanto P, McKenzie SE, Williams KJ. Cholesterol enrichment of human monocyte/ macrophages induces surface exposure of phosphatidylserine and the release of biologically-active tissue factorpositive microvesicles. Arteriosclerosis, Thrombosis, and Vascular Biology. 2007;27(2):430-5.

14. Sugiarti L, Latifah L. Hubungan Obesitas, Umur Dan Jenis Kelamin Terhadap Kadar Kolesterol Darah. Jurnal Kesehatan. 2017;1(1):84.

15. Ramos R, Comas-Cufí M, Martí-Lluch R, Balló E, Ponjoan A, Alves-Cabratosa $\mathrm{L}$, et al. Statins for primary prevention of cardiovascular events and mortality in old and very old adults with and without type 2 diabetes: Retrospective cohort study. British Medical Journal. 2018;362:1-4.

16. Brown F, Singer A, Katz A, Konrad G. Statin-prescribing trends for primary and secondary prevention of cardiovascular disease. Canadian Family Physician. 2017;63(11):e495-503. 